Diş hekimlerinin

enfeksiyon kontrolü,

sterilizasyon ve

dezenfeksiyon

konusundaki duyarlılık

ve uygulamaları

\section{Susceptibility and application of dentists in dental infection control, sterilization and disinfection}

Dr. Öğr. Üyesi İsmail Gümüşsoy

Sakarya Üniversitesi Diş Hekimliği Fakültesi, Ağız Dis ve Cene Radyolojisi A.D., Sakarya

Orcid ID: 0000-0002-2725-3273

Dt. Fikriye Kartal

il Sağlık Müdürlüğü,

Agız Diş Sağlığı Hizmetleri, Sakarya

Orcid ID: 0000-0002-2718-620X

Dr. Öğr. Üyesi Doğukan Yılmaz

Sakarya Üniversitesi Diș Hekimliği Fakültesi, Periodontoloji A.D., Sakarya

Orcid ID: 0000-0003-2576-0885

\section{Dr. Hande Toptan}

Sakarya Üniversitesi, Tıp Fakültesi,

Tibbi Mikrobiyoloji A.D., Sakarya

Orcid ID: 0000-0001-6893-8490

Doç. Dr. Selma Altındiş

Sakarya Üniversitesi, İşletme Fakültesi,

Sağlık Yönetimi A.D., Sakarya

Orcid ID: 0000-0003-2805-5516

\section{Dr. Öğr. Üyesi Suayip Burak Duman}

İnönü Üniversitesi Diş Hekimliği Fakültesi,

Ağız Dis ve Cene Radyolojisi A.D., Malatya

Orcid ID: 0000-0003-2552-0187

Geliș Tarihi: 18 Șubat 2019

Kabul Tarihi: 12 Eylül 2019

doi: 10.5505/yeditepe.2019.53315

\section{Yazıșma adresi:}

\section{Dr. İsmail Gümüşsoy}

Ağız Diş ve Çene Radyolojisi,

Dis Hekimliği Fakültesi, Sakarya Üniversitesi,

Sakarya, Türkiye

İs Telefon: +90 2642954201

Fax: +902642954203

E-posta: ismgum@gmail.com
ÖZET

Amaç: Kan ve diğer vücut sıvıları ile bulaşan hastalıklardaki artış diş hekimliği çalışma alanlarında hastalık bulaşının önlenmesinde standart enfeksiyon protokollerinin uygulanması konusunda diş hekimliği çalışanlarında bir farkındalık oluşturmaktadır. Bu protokoller hem hastaları hem de dental çalışanları korumaya yönelik oluşturulmuştur. Bu çalışmanın amacı diş hekimlerinin enfeksiyon kontrolü, sterilizasyon ve dezenfeksiyon konusundaki mevcut uygulamalarının ve duyarlıığının araştırıımasıdır. Gereç ve Yöntem: Bu çalışma Türkiye'nin farklı illerinde kamu ve özelde aktif çalışan toplam 102 diş hekiminin katıımıyla gerçekleştirilmiştir. Araştırmaya katılan hekimlere sterilizasyon, dezenfeksiyon ve enfeksiyon kontrolü konulu 28 soruluk bir anket uygulanmıştır.

Bulgular: Hekimlerin \%65'i aerotör/agludruva gibi aletlerin dezenfektan solüsyonlar ile silinmesinin yeterli olmadığını ve her hastada steril edilmesi gerektiğini belirtmesine rağmen hekimlerin ancak $\% 58^{\prime} i$ aerotör/ angludruvayı her hastada steril ettiklerini belirtmiştir. Hekimlerin \%40'ı dental tedaviler öncesi ellerini sabun/el dezenfektanı ile yıkadığını, \%15'i ise bazen yıkamadığını belirtmiştir. Hekimlerin \%81'i her zaman maske kullanmaktadır. Ancak hekimlerin sadece \%34'ü maskeyi her hastada değiştirdiğini söylemiştir. Hekimlerin \%10'nu koruyucu gözlük/siperi hiç kullanmadığını, \%32'si ise her zaman kullandığını, \%47'si ise her hastada dezenfekte ettiğini belirtmiştir. \%56 oranında hekim tedavi esnasında koruyucu giysi kullanmaktadır. Hekimlerin ancak \%43'ü enjektör ucunu tek el tekniği ile kapattığını belirtmiştir. Katılımcıların \%25'i hastanın tedavisi esnasında temas edilen yüzeyleri su geçirmez bariyerlerle kaplarım/ kaplanmasını sağlarım şeklinde ifadede bulunmuştur. Hekimlerin \%25'i ise bu işlemi hiçbir zaman yapmadığını söylemiştir. Hastanın tedavisi sırasında kontamine aeresollerin sıçramasını engellemek için her zaman emiş gücü yüksek aspirator kullanan hekim oranı ise $\% 47^{\prime}$ dir. Hekimlerin \%68'i sterilize edilemeyen ortak kullanılan aygıtları kullanımdan sonra dezenfekte ederim/ edilmesini sağlarım ifadesinde bulunurken, $\% 10^{\prime} u$ bunu nadiren yaptığını belirtmiştir.

Sonuç: Diş hekimliği çalışanları yüksek oranda enfeksiyon riski taşıyan bir ortamda çalışmaktadırlar ve hem kendilerini hem de hastaları çapraz enfeksiyondan korumak yükümlülüğündedirler. Bu çalışmanın sonuçları hekimlerin enfeksiyon kontrolü, sterilizasyon ve dezenfeksiyon konularında daha dikkatli davranmaları gerektiğini ortaya koymaktadır.

Anahtar kelimeler: Çapraz enfeksiyon, sterilizasyon, dezenfeksiyon, diş hekimi

\section{SUMMARY}

Aim: The increase in diseases transmitted with blood and other body fluids constitutes an awareness in dentistry 
staff about the implementation of standard infection protocols in the prevention of disease transmission in dental clinics. These protocols are designed to protect both patients and dentists. The aim of this study was to investigate the current attitude and susceptibility of dentists in infection control, sterilization and disinfection.

Materials and Methods: This study was conducted with the participation of public and private employees in a total of 102 dentists in different provinces of Turkey. This study consisted of a 28-item questionnaire on sterilization, disinfection and infection control.

Results: Although $65 \%$ of physicians stated that it was not enough to disinfect instruments such as aerotor with disinfectant solutions and should be sterilized in each patient, only $58 \%$ of the physicians stated that they had sterilized the aerotor in each patient. $40 \%$ of the dentists stated that they washed their hands with soap / hand disinfectants before dental treatments and $15 \%$ of the dentists did not wash them. $81 \%$ of dentists always use masks. However, only $34 \%$ of the dentists said that they changed the mask in every patient. $10 \%$ of the dentists never use the protective goggles / shields, $32 \%$ of them use it all always, $47 \%$ of of the dentists disinfect it each patient. $56 \%$ of the dentists use protective clothing during treatment. Only $43 \%$ of the dentists stated that they closed the injector tip with one hand technique. $25 \%$ of the participants stated that they covered with waterproof barriers the surfaces that were contacted during the treatment of the patient. $25 \%$ of the dentists said that they never did this process. In order to prevent the splashing of contaminated aerosols during treatment, the rate of dentist using aspirator is $47 \% .68 \%$ of the dentists stated that they disinfect common devices which cannot be sterilized after use and $10 \%$ said that they rarely do this.

Conclusion: Dentists usually work in an environment with high risk of infection and are obliged to protect themselves and patients from cross-infection. The results of this study reveal that dentists should be more careful about infection control, sterilization and disinfection.

Keywords: Cross enfection, sterilization, disinfection, dentist

\section{GíRiş}

Dünyanın 80'li yıllarda Human Immuno deficiency Virus (HIV)'in neden olduğu yeni bir ölümcül bulaşıcı hastalıkla tanışması ve akabinde 90'lı yılların başında Amerika'da bir diş hekimi muayenehanesinde 6 hastaya HIV virüsünün bulaştııılığının ortaya çıkması çapraz enfeksiyonla mücadele kavramının diş hekimliğinde daha fazla öne çıkmasına neden olmuştur. ${ }^{1}$ Günümüzde de kan ve diğer vücut sıvıları ile bulaşan hastalıklardaki artış diş hekimliği çalışma alanlarında hastalık bulaşının önlenmesinde standart enfeksiyon protokollerinin uygulanması konusunda diş hekimliği çalışanlarında güncel bir farkındalık oluşturmaktadır. Bu protokoller hem hastaları hem de dental çalışanları korumaya yönelik oluşturulmuştur. ${ }^{2,3}$ Hastalık yayıım riskini en aza indirmek için uluslararası kuruluşların tavsiye ettiği temel enfeksiyon kontrol önlemleri özetle şunları içermektedir; Eldiven giymeden önce ve sonra düzenli olarak el hijyeninin sağlanması, kişisel koruyucu bariyer tekniklerinin uygulanması (eldiven, maske, koruyucu gözlük vs. gibi), klinik prosedürler esnasında ve aletleri temizlerken ve yeniden kullanıma sokarken uygun koruyucu ekipman kullanmak, etkili bir şekilde çevresel temizlikle ilgili kuralların uygulanması, belirtilen yerlerde aseptik temassız tekniklerin kullanıması, klinik önlüklerin uygun şekilde kullanılması ve uygun yerlerde yüzeylerin, kontamine olmuş ve temizlemesi zor maddelerin plastik kaplamalar ile izole edilmesidir. ${ }^{4}$ Enfeksiyonlar direkt olarak kan, oral veya diğer vücut sıvıları ile bulaşabileceği gibi, kontamine aletler, kontamine yüzeyler, ağız ya da solunum yolundan kaynaklı sıvıların aerosol şeklinde etrafa saçılması ile indirekt yolla da bulaşabilir. Tüm bunlar göz önüne alındığında enfeksiyon kontrolünün amacl; patojen mikroorganizmaların azaltılması, çapraz enfeksiyonların önlenmesi için potansiyel enfekte bütün instrümanların ve hastaların rehabilite edilmesi, hasta ve personelin enfeksiyondan korunması, enfeksiyon kontrolü, sterilizasyon ve dezenfeksiyon konusunda öğrencilerden başlanarak bütün personelin gerekli eğitimi almasının sağlanmasıdır. ${ }^{5-7}$

Diş hekimleri hastaların sağlıklı ağızlara ve onları memnun edecek restorasyonlara kavuşmalarını mesleklerinin bir gereği olarak gördükleri gibi hastalarını çapraz enfeksiyondan korumayı da hekimlik mesleğinin önemli bir parçası olarak görmelidir. Bu çalışmanın amacı diş hekimliği çalışanları arasında enfeksiyon kontrolü, sterilizasyon ve dezenfeksiyon konusundaki mevcut uygulamaların ve duyarlıı̆̆ın araştırılmasıdır.

\section{GEREÇ VE YÖNTEM}

Bu çalışma Türkiye'nin farklı illerinde kamu ve özelde aktif çalışan toplam 102 diş hekiminin katılımıyla gerçekleştirilmiştir. Çalışmada gerçekleştirilen tüm prosedürler, kurumsal ve ulusal araştırma komitesinin etik standartlarına (etik başvuru no: 03/09/2018-E.11447) ve 1964 Helsinki beyanına ve daha sonraki değişikliklere veya karşılaştırılabilir etik standartlara uygun olarak yapıldı. Araştırmaya katılan kişilere sterilizasyon, dezenfeksiyon ve enfeksiyon kontrolü konulu 28 soruluk bir anket uygulanmıştır. Ankette hekimlere çapraz enfeksiyon kontrolü, sterilizasyon ve dezenfeksiyon konusundaki duyarlıık ve uygulamaları ile ilgili sorular ve yaş, cinsiyet, uzmanlık alanı ve hangi kurumda çalıştıkları gibi tanımlayıcı birtakım sorular sorulmuştur. Sorular çoktan seçmeli veya evet hayır şeklinde cevaplanabilecek nitelikte oluşturuldu. Anket sonuçları istatistiksel olarak değerlendirildi ve ver- 
ilerin analizinde Ki kare testi kullanıldı.

\section{SONUÇLAR}

\%40 oranıyla katıımcıların çoğunluğunu 23-29 yaş aralığındaki ortalama 5 yıllık mesleki tecrübeye sahip hekimler oluşturmuştur. Hekimlerin \%60'ı herhangi bir uzmanlığı olmayan diş hekimiydi. \%83 oranıyla hekimlerin oldukça büyük bir kısmı konuyla ilgili daha önce meslekiçi eğitim aldıklarını belirtmiştir (Tablo 1).

Tablo 1. Anket çalışmasına katılan hekimlerin yaş, cinsiyet, uzmanlık alanı ve hagi kurumda çalıştıkları gibi tanımlayıcı bilgilere ait sayı ve yüzdeler

\begin{tabular}{|c|c|c|}
\hline Cinsiyet & Yüzde & Sayı \\
\hline Erkek & 49 & 50 \\
\hline Kadın & 51 & 52 \\
\hline \multicolumn{3}{|l|}{ Yaş arahọ̆ } \\
\hline $23-29$ & 40 & 41 \\
\hline $30-39$ & 37,3 & 38 \\
\hline $40-49$ & 14,7 & 15 \\
\hline $50+$ & 7,8 & 8 \\
\hline \multicolumn{3}{|l|}{ Meslekteki yllmzz } \\
\hline $1-5$ & 38,2 & 39 \\
\hline $6-10$ & 27,5 & 28 \\
\hline $11-15$ & 14,7 & 15 \\
\hline $15+$ & 19,6 & 20 \\
\hline \multicolumn{3}{|l|}{ Ünvan } \\
\hline Diş hekimi & 54,5 & 55 \\
\hline Uzman/doktora & 23,8 & 24 \\
\hline Dr Öğretim üyesi & 13,9 & 14 \\
\hline Doçent & 2 & 2 \\
\hline Profesör & 5,9 & 6 \\
\hline \multicolumn{3}{|l|}{ Uzmanlık/doktora alamı } \\
\hline Ağız diş ve çene cerrahisi & 4 & 4 \\
\hline Ağız diş ve çene radyolojisi & 16,8 & 17 \\
\hline Diş hastalıkları ve tedavisi & 3 & 3 \\
\hline Endodonti & 3 & 3 \\
\hline Ortodonti & 2 & 2 \\
\hline Pedodonti & 4 & 4 \\
\hline Periodontoloji & 6,9 & 7 \\
\hline Protetik diş tedavisi & 8,9 & 9 \\
\hline \multicolumn{3}{|l|}{ Calștığmnz kurum } \\
\hline Muayenehane & 15 & 15 \\
\hline Özel poliklinik & 17 & 17 \\
\hline Kamu hastanesi & 30 & 30 \\
\hline Üniversite hastanesi & 38 & 38 \\
\hline
\end{tabular}

Hekimlerin \%39'u dental tedaviler öncesi ellerini sabun/el dezenfektanı ile yıkadığını, \%14'ü ise bazen yıkamadığını belirtmiştir. Tedavi sonrası el yıkama ile ilgili soruda da benzer cevaplar alınmıştır. Hekimlerin \%96'sı dental tedavilerde eldiven giydiğini, tamamı ise her hastada eldiveni değiștirdiğini söylemiştir. Hekimlerin \%83'ü maske kullanmaktadır. Ancak hekimlerin sadece \%34'ü maskeyi her hastada değiştirdiğini söylemiştir. Hekimlerin \%10'u koruyucu gözlük/siperi hiç kullanmadığını, \%35'i ise her zaman kullandığını, \%44'ü ise her hastada dezenfekte ettiğini belirtmiştir. \%56 hekim tedavi esnasında koruyucu giysi kullanmaktadır. Hekimlerin ancak \%43'ü enjektör ucunu tek el tekniği ile kapattığını belirtmiştir. Hekimlerin \%40'ı dezenfektan solüsyonlar ile ilgili bir soruya bu solüsyonlara güvenmediklerini belirterek cevap vermiştir. Katılımcıların \%20'si hastanın tedavisi esnasında temas edilen yüzeyleri (hava-su spreyi, ünit kontrol panelleri, tabla tutacakları, reflektör kolları, koltuk başları alüminyum folyo, streç film, plastik örtücüler) su geçirmez bariyerlerle kaplarım/kaplanmasını sağlarım şeklinde ifadede bulunmuştur. Hekimlerin \%70'i aerotör gibi aletlerin dezenfektan solüsyonlar ile silinmesinin yeterli olmadığını ve her hastada steril edilmesi gerektiğini belirtmesine rağmen hekimlerin ancak \%58'i aerotör-angludruvayı her hastada steril ettiklerini belirtmiştir. Hekimlerin \%17'si ise her hastadan sonra temas eden yüzey- lerdeki koruyucu bariyerleri değiştiririm/değiştirilmesini sağlarım, ünit ve çevresini dezenfektan ajanlarla silerim/ silinmesini sağlarım demiştir. Hastanın tedavisi sırasında kontamine aeresollerin sıçramasını engellemek için her zaman emiş gücü yüksek aspirator kullanan hekim oranı ise $\% 45^{\prime}$ dir. Hekimlerin $\% 70$ 'i sterilize edilemeyen ortak kullanılan aygıtları (ölçü materyali tabancaları, ışık cihazı, renk skalası gibi) kullanımdan sonra dezenfekte ederim/ edilmesini sağlarım ifadesinde bulunurken, \%10'u bunu nadiren yaptığını belirtmiş̧ir.

Hekimlerin cinsiyet, yaş grubu, meslekteki yılı, varsa uzmanlık alanı ve çalıştığı kurum bilgileri gibi parametreler ve enfeksiyon kontrolü, sterilizasyon ve dezenfeksiyon konusundaki mevcut uygulama ve duyarlılıkları arasında istatiksel olarak anlamlı bir farklıık bulunmadı.

\section{TARTIŞMA}

Diş hekimlerinin mesleklerini icra ederken tüberküloz, influenza, hepatit gibi viral ya da bakteriyel bulaşıcı hastalıklara maruz kalma hususunda diğer meslek gruplarına nazaran daha fazla risk aldıkları ortadadır. Özellikle hepatit $\mathrm{B}$ virüsü ile enfekte olma riskinin diş hekimlerinde, normal popülasyona göre 5 misli daha fazla olduğu literatürde yer almaktadır. ${ }^{2-7}$

Muayenehane pratiğinde, genel ameliyathane şartları olmaksızın, gömülü diş çekimi, implant operasyonu vs. gibi invaziv işlemlerin her zaman kolaylıkla yapılıyor olması hem diş hekimlerinin hem de hastaların çapraz enfeksiyon riski ile kolayca yüzleşmesine olanak sağlamaktadır. Bu konuda hem hastanın hem de kendisinin korunması hekimin sorumluluğundadır. Bu nedenle diş hekimliği kliniklerinde enfeksiyon kontrolü, sterilizasyon ve dezenfeksiyon ile ilgili uygulamalar oldukça önem arz etmektedir.

Çalışmanın sonuçlarına göre hekimlerin ne yazık ki büyük çoğunluğu kullandıkları maskeyi her hastada değiştirmemektedir ve hekimlerin ancak yarısı emiş gücü yüksek aspiratörleri kullanmaktadır. Yüz maskeleri dental operasyon esnasında hastalardan yayılan aerosollerin diş hekimliği çalışanları tarafından inhale edilmesi yoluyla meydana gelen çapraz enfeksiyon riskini ciddi oranda azaltan koruyucu ekipmanlardır. Üstelik bu aerosoller influenza ve tüberküloz gibi ciddi bulaşıcı hastalıklara sebep olan patojen mikroorganizmaları kolaylıkla taşıyabilmektedir. Ayrıca bu aerosoller ile tükrük, kan, diş ve restoratif materyallere ait partiküller ve çeşitli mikroorganizmalar da taşınabilmektedir. Yüksek hızlı hava türbinleri ile dönen aletler ve ultrasonik periodontal aletler de oldukça büyük miktarlarda aerosol üretimine neden olmakta ve bu aerosoller hastadan 2 metre uzağa, yani diş hekimliği çalışanlarının kolaylıkla soluyabileceği bir mesafeye yayılmaktadır. Bu partiküllerin göz vb. yollarla vücut boşluklarına ulaşmasının engellenmesi amacıyla sadece maske değil diğer koruyucu siperlerin kullanımı da diş hekimliğinde 
oldukça önemlidir. Yine bu aerosollerin etrafa yayılımının azaltııması için emiş gücü yüksek aspiratörlerin kullanımı da önemlidir. 3,8-11

Ülkemizde hepatit B virüs enfeksiyonlarının yaygınlığı ve hekimlerin kesici delici alet yaralanmalarına maruz kalma sebeplerinin başında iğne batması olduğu dikkate alındığında hekimlerin kendilerini enfeksiyondan korumada tek el tekniği ile enjektör kapatma yönteminin önemi ortaya çıkmaktadır. Cleveland ve ark. ${ }^{12}$ diş hekimliğinde meydana gelen kesici-delici alet yaralanmalarının dörtte birinin iğne batması sonucu olduğunu belirtirken Türkiye'de Uri ve ark. yaptığı bir çalışmada ise bu oranın \%50'ye yakın olduğu rapor edilmiştir. Aynı çalışmada Uri ve ark. yaralanmaya neden olan aletlerin \%60'ının kontamine olduğunu söylemiştir. Anketimize katılanların $\% 57$ 'sinin tek el tekniği ile enjektör kapatma yöntemini tercih etmediğini söylemesi hekimlerin bu konuda risk altında olduklarının yeterince farkında olunmadığının bir göstergesidir. 2,13-15

Anket sorularından elde edilen verilere göre hekimlerin büyük bir çoğunluğu dezenfektan solüsyonların istenen düzeyde etkinliğe sahip olmadığına ve aerotor/mikromotor gibi aletlerin bu solüsyonlarla silinerek kullanılmasının doğru olmadığına inandıklarını belirtmelerine rağmen \%42 gibi hatırı sayılır bir oranda hekim aerotor/mikromotoru her hastada steril etmediklerini belirtmiştir. Konuyla ilgili yapılan literatür araştırmalarına göre aerotor/mikromotor gibi aletler dental tedaviler esnasında ciddi anlamda bir potansiyel çapraz enfeksiyon sebebi olduğu ve her hastada steril edilmesinin zorunlu olduğu belirtilmiştir. ${ }^{3,4,7}$ Hava-su spreyi, ünit kontrol panelleri, tabla tutacakları, reflektör kolları ve koltuk başları alüminyum folyo, streç film, plastik örtücüler gibi su geçirmez bariyerlerle kaplanmalı ve her hastada değiştirilmeli ya da EPA onaylı dezenfektanlar ile yeterli miktar ve sürede temizlenmelidir. Hem aerosoller hem de eldiven temasıly bu bölgelerinde potansiyel enfekte olduğu unutulmamalıdır. Çalışmaya katılan hekimlerin \%25'i bu işlemi her hastada yaptığını söylemiştir. Yine aynı şekilde ölçü materyali tabancaları, ışık cihazı, renk skalası gibi ortak kullanılan aygıtlarda da durum benzerdir. ${ }^{4,6,16,17}$

Diş hekimliği çalışanları yüksek oranda enfeksiyon riski taşıyan bir ortamda çalışmaktadırlar. Hekimlerin hem kendilerini hem de hastaları çapraz enfeksiyondan korumaları temel mesleki yükümlülüklerindendir. Bu çalışmanın sonuçları hekimlerin enfeksiyon kontrolü, sterilizasyon ve dezenfeksiyon konularında daha dikkatli davranmaları gerektiğini ve konuyla ilgili meslek-içi eğitimlere daha etkin bir şekilde katılmalarının önemini ortaya koymaktadır. Aynı şekilde hekimlerin bağlı bulundukları dernek ya da kurumlarda bu konuda denetleme ve eğitim mekanizmalarını daha aktif hale getirmelidir.

\section{KAYNAKLAR}

1. Update--transmission of HIV infection during an invasive dental procedure--Florida. MMWR Morbidity and mortality weekly report. 1991; 40: 21-27.

2. Samaranayake L. Rules of infection control. Int Dent $J$ 1993; 43: 578-584.

3. Kohn WG, Collins AS, Cleveland JL, Harte JA, Eklund $\mathrm{KJ}$, Malvitz DM. Guidelines for infection control in dental health-care settings--2003. MMWR Recommendations and reports: Morbidity and mortality weekly report Recommendations and reports. 2003; 52: 1-61.

4. (ADA) ADA. Guidelines for Infection Control 2nd ed. 2009.

5. Verrusio AC, Neidle EA, Nash KD, Silverman $S$, Jr., Horowitz AM, Wagner KS. The dentist and infectious diseases: a national survey of attitudes and behavior. J Am Dent Assoc (1939). 1989; 118: 553-562.

6. Girdler NM, Matthews RW, Scully C. Use and acceptability of rubber gloves for outpatient dental treatment. J Dent 1987; 15: 209-212.

7. Palenik CJ, Burke FJ, Miller $\mathrm{CH}$. Strategies for dental clinic infection control. Dent update. 2000;27:7-10

8. Craig DC, Quayle AA. The efficacy of face-masks. $\mathrm{Br}$ Dent J 1985; 158: 87-90.

9. Travaglini EA, Larato DC. A disposable dental face mask with a plastic eye shield for operating with the air turbine drill. The Journal of prosthetic dentistry. 1965;15:525527.

10. Vig RG. Reducing laboratory aerosol contamination. J Prost Dent 1969; 22: 156-157.

11. Micik RE, Miller RL, Mazzarella MA, Ryge G. Studies on dental aerobiology. I. Bacterial aerosols generated during dental procedures. J Dent Res 1969; 48: 49-56.

12. Cleveland JL, Barker LK, Cuny EJ, Panlilio AL. Preventing percutaneous injuries among dental health care personnel. J Am Dent Assoc (1939). 2007; 138: 169-178

13. Siew $C$, Chang SB, Gruninger $S E$, Verrusio AC, Neidle EA. Self-reported percutaneous injuries in dentists: implications for HBV, HIV, transmission risk. J Am Dent Assoc (1939). 1992;123: 36-44.

14. Younai FS, Murphy DC, Kotelchuck D. Occupational exposures to blood in a dental teaching environment: results of a ten-year surveillance study. J Dent Educ 2001; 65: 436-448.

15. Machado-Carvalhais HP, Martins TC, Ramos-Jorge ML, Magela-Machado D, Paiva SM, Pordeus IA. Management of occupational bloodborne exposure in a dental teaching environment. J Dent Educ 2007; 71: 1348-1355. 16. Goldman HS, Hartman KS. Infectious diseases. Their disease, our unease: infectious diseases and dental practice. Virgin Dent J 1986; 63: 10-19.

17. Wood PJ. Infection control practices of Rhode Island dental hygienists and certified dental assistants. J Dent Hygiene 1995; 69: 212-222. 